was about $16 \mathrm{~km}$ to the south in the Missouri Coteau; the closest wooded valley was the Anerley Lakes chain $29 \mathrm{~km}$ to the northeast. The presence of a Ruffed Grouse in this locale was remarkable.

Contributing to the oddity of the occurrence was the site itself: the grouse was $50 \mathrm{~m}$ into clean summerfallow about $200 \mathrm{~m}$ east of a shelterbelt arid $25 \mathrm{~m}$ west of a small, shallow creek bed. The dry creek bed had tall grasses, weeds, scattered buckbrush and small willow bushes, but no trees.

We surmised that the grouse was caught moving her brood between shelterbelt and creek. But why she was there, why she was making the move and why she did not travel through the roadside grasses were unknowns. The observation was unusual.
I am grateful to Ken Giesbrecht and Jim Slimmon for comments on their respective interests in this article.

${ }^{\top}$ FAST,D. 1979. Grouse flying crazy and dancing high. Blue Jay 37:219-220.

${ }^{2}$ FRIESEN, V.C. 1971. The crazy flight phenomenon of the Ruffed Grouse. Blue Jay 29:121-124.

3 1978. Further observations of the Ruffed Grouse's "crazy-flight." Blue Jay 36:192-199.

4 1980. Crazy grouse comment. Blue Jay 38:135-136.

${ }^{5}$ SALT, W.R. and J.R. SALT. 1976. The birds of Alberta. Hurtig Publishers, Edmonton. 498 pp.

\title{
BRIEF OBSERVATIONS OF PEREGRINE AND PRAIRIE FALCON BEHAVIOUR
}

\author{
RUDOLF F. KOES, 135 Rossmere Crescent, Winnipeg, Manitoba. R2K 0G1
}

Thinking of large falcons almost invariably conjures up images of power and agility. The popular literature abounds with tales of Peregrine or Prairie falcons seen pursuing prey, if not with the speed of light, then at least faster than a speeding bullet. Sometimes, however, falcons find themselves in more pedestrian situations, as described here.

Peregrine Falcons are the only large falcons regularly observed in Winnipeg. They are most often seen migrating through the city in early May and again in late September. On 25 September 1986, a rainy and windy day, one Peregrine, likely a male, had made a few low, sweeping passes over Fraser's Grove Park in Winnipeg. As it came over once more, in a wide circle on outspread wings, a large moth was carried in its direction by the strong south wind. Their paths closed. The Peregrine tilted slightly to alter its course and, while on its side, attempted to grasp the insect in its talons. The moth was momentarily lost from sight, but then it reappeared, fluttering along again in the wind. The falcon did not try again; it merely continued its barely interrupted circling flight.

I watched the incident through $7 \times 42$ Leitz Trinovid binoculars at a distance of $30-40 \mathrm{~m}$. Although I am not familiar enough with moths to identify them to species at that distance (who is?), the insect was perhaps $2.5 \mathrm{~cm}$ long, with a wingspan of 4 to $5 \mathrm{~cm}$, and it appeared brownish. 
On 6 November 1988, after a productive day of birding, Gordon Grieef, George Holland, Russell Tkachuk and I were on our way home in the late afternoon. While driving along Provincial Road 304 east of the hamlet of Stead, Manitoba, we spotted a large flock of small birds approaching us. The birds turned out to be Snow Buntings, about 500 of them. Imagine our surprise on seeing a Prairie Falcon at the head of the flock, then a second Prairie Falcon near the first. The mob passed overhead, the falcons silently, the buntings constantly calling. A similar-sized flock of buntings arose from a plowed field, wheeled around once and joined the chase 1000 chattering little birds, appearing to drive the falcons away, but in reality trying hard to keep up with their leisurely cruising adversaries, gradually disappearing to the east.

Mobbing of avian predators is not uncommon among passerines and it appears that Snow Buntings do so regularly. Peter Taylor saw about 500 Snow Buntings fly up to chase a passing male Merlin near Seven Sisters in October 1982. ${ }^{4}$ Perhaps this may be explained by the fact that Gyrfalcons and Peregrine Falcons often prey on Snow Buntings. Parmelee (in Bent) wrote: "Bunting remains are often numerous at gyrfalcon and peregrine falcon aeries. The gyrfalcons commonly follow the bunting hordes along the coasts in fall; one that MacDonald and I shot had just eaten four buntings." 3

The best place in southeastern Manitoba to see a Prairie Falcon is Oak Hammock Marsh. From August to October one can usually find anywhere from one to four of these magnificent birds creating panic among the ducks and shorebirds. While birding there on 3 September 1979, David and Madelyn Hall and I witnessed an encounter that had none of the usual dash. A Prairie Falcon was perched on a clump of earth on the bank of a drainage ditch at the north end of the marsh. Nearby swam a Lesser Yellowlegs, probably driven into the water while trying to escape the falcon. The
Prairie Falcon repeatedly tried to pick the shorebird off the surface. It would flap quite slowly, almost hovering, from one side of the ditch to the other, each time passing low over its intended prey, which at the last moment would avoid the raptor by diving under water. Each time the falcon would land on the same clump or one on the other side and sit for a moment. It made at least 20 passes, but it did not seem to get any closer to succeeding. Hoping to get a better look, we slowly drove our car to the side of the ditch. The birds were temporarily lost from sight as we rounded an observation mound. When the other side of the mound was reached, a matter of a few seconds, the falcon was tearing at its prey. It was hard to believe, but a close look revealed that the prey was indeed the hapless yellowlegs. Persistence, not great speed, had paid off.

A number of accounts of shorebirds evading falcons by diving into the water have previously appeared in Blue Jay. Lahrman witnessed a Prairie Falcon swooping at a Lesser Yellowlegs at Wascana Waterfowl Park in Regina in September 1957. The standing yellowlegs escaped by diving beneath the surface and the falcon flew away. ${ }^{1}$ Wallace reported a similar incident when a young Peregrine Falcon drove a Semipalmated Sandpiper out of the air into the water and made three unsuccessful passes at it. The sandpiper submerged each time and returned to the beach after the falcon gave up. ${ }^{5}$ Nero saw a flock of Longbilled Dowitchers escape a Peregrine Falcon near Regina by hitting or diving into the water of a small pond. One dowitcher flew off by itself and the falcon flew after it. "Just as the Peregrine closed in on it the dowitcher dived into the water and the hawk overshot its position." 2

Diving below the surface of the water is clearly a method of escaping large falcons which is often successful for shorebirds. 


\section{Acknowledgements}

Robert Nero and Peter Taylor were most helpful by commenting on a draft of the manuscript and by bringing a number of sightings to my attention. I thank them both.

${ }^{1}$ LAHRMAN, F. 1957. A quick-witted yellowlegs. Blue Jay 15:146.

${ }^{2}$ NERO, R.W. 1958. Attempted predation by Peregrine Falcon observed at Regina. Blue Jay 16:114.
${ }^{3}$ PARMELEE, D.F. In BENT. 1968. Life histories of North American cardinals, grosbeaks, buntings, towhees, finches, sparrows, and allies. U.S. Nat. Mus. Bull. 237, Smithsonian Institution Press, pp. 1652-1675.

${ }^{4}$ TAYLOR, P. 1983. Wings along the Winnipeg: the birds of the Pinawa-Lac du Bonnet region, Manitoba. Man. Nat. Soc. Eco Series No. 2, Winnipeg, Manitoba. 216 pp.

${ }^{5}$ WALLACE, R. 1958. Attempted predation by Peregrine Falcon observed at Toronto Island. Blue Jay 16:114.

\section{GREENWATER LAKE BIRDS - A PERSONAL REMINISCENCE OF THE 1940s}

DAVID H. WRIGHT, 1601-415 Heritage Crescent, Saskatoon, Saskatchewan. S7H 5N3

Greenwater Lake is situated in one of Saskatchewan's provincial parks. Now it is a well-developed summer resort with a trailer park, ample sandy beaches and most of the amenities North Americans expect during a summer vacation. When I was a teenager, the park was not nearly so sophisticated.

The lake is located in the east-central portion of the province in a well-treed area that might best be described as deciduous parkland. During the late 1940s, my parents acquired a small cottage after struggling for several years with a shack tent. The cottage was comfortable, but very modest. A small screened porch on the front served as an additional sleeping area.

Our summer vacations can only be described as idyllic. We spent our days fishing, swimming, exploring the woods on foot, and the lake and its creeks by boat. Swimming trunks were our summer uniforms.
In 1944, I was given Taverner's Birds of Canada. I later acquired a companion volume entitled Water Birds of Canada by the same author. With these books, a passing interest in birds developed into a lifelong hobby. For the first time, I observed that the so-called "Hell-diver" pointed out to me by others had plumage quite different to that of the loon. I discovered the numerous small "ducks" I saw swimming the reedy borders of the lake were not ducks at all, but something called coots. And so it went. The observations recorded below were made in the years 1944 through 1947 and characteristically in each year between approximately 25 June and 30 August. The one exception relates to the sighting of the White-breasted Nuthatch which I saw in the fall of 1947 while visiting Nut Mountain Lake.

The self-taught ornithologist is a sorry student. His mistakes are many, his progress (if any) slow. He may labour for years, learning what the professionally- 